\title{
Structural Properties Analysis of Mg- $\beta$-TCP by X-ray Powder Diffraction with the Rietveld Refinement
}

\author{
Asmaa Massit ${ }^{1(D)}$, Majda Fathi ${ }^{1}$ (D), Ahmed El Yacoubi 1 ${ }^{(D)}$, Mohamed Salaheddine El Youbi ${ }^{\text {(iD), }}$ \\ Brahim Chafik El Idrissi 1,* (D) \\ 1 Laboratory of Advanced Materials and Process Engineering, Faculty of Sciences, Ibn Tofail University, Kenitra, Morocco; \\ massit.asma@gmail.com (A.M.); fathimajda@hotmail.com (M.F.); elyacoubi6ahmed@gmail.com (A.E.Y.); \\ mselyoubi@yahoo.fr (M.S.E.Y); chidrissi@yahoo.fr (B.C.E.I.); \\ * Correspondence: chidrissi@yahoo.fr;
}

Received: 1.08.2020; Revised: 15.08.2020; Accepted: 16.08.2020; Published: 18.08.2020

Abstract: The incorporation of magnesium in the synthetic apatite has been associated with the biomineralization process and osteoporosis therapy in humans and animals. $\beta$-tricalcium phosphate ( $\beta$ TCP) is one of the most common bioceramics widely applied in bone cement and implants. In this work, Ca-deficient apatite $(\mathrm{CDA})$ with a theoretical $0.08 \mathrm{Mg} /(\mathrm{Ca}+\mathrm{Mg})$ ratio was synthesized by the rapid reaction between $\mathrm{Ca}(\mathrm{OH})_{2}, \mathrm{MgCl}_{2} \cdot 6 \mathrm{H}_{2} \mathrm{O}$ and $\mathrm{H}_{3} \mathrm{PO}_{4}$ at $40^{\circ} \mathrm{C}$ and the resultant powder calcined at 650 ${ }^{\circ} \mathrm{C}$ for $10 \mathrm{~h}$. X-ray powder diffraction analysis (XRD), in combination with the Rietveld method (Fullprof-suite), was employed for quantitative phase analysis and structural refinement. The results of XRD indicate that magnesium can substitute for calcium into a $\beta$-TCP structure inducing a reduction of the cell parameters and the compound crystallizes in the rhombohedral R3c structure, with the following unit cell constants: $\mathrm{a}=\mathrm{b}=10.3560 \AA \mathrm{A}, \mathrm{c}=37.1718 \AA$, and cell volume $\mathrm{V}=3452.44$. The analysis indicated that the substitution of $\mathrm{Mg}^{2+}$ on the $\mathrm{M}(4)$ and $\mathrm{M}(5)$ sites were, approximately, 2.61 and $6.97 \mathrm{~mol} \%$, corresponding to the $\mathrm{Ca}_{2.72}\left(\mathrm{Mg}^{\mathrm{IV}}{ }_{0.07}, \mathrm{Mg}^{\mathrm{V}}{ }_{0.21}\right)\left(\mathrm{PO}_{4}\right)_{2}$ stoichiometric formula and 0.09 $\mathrm{Mg} /(\mathrm{Ca}+\mathrm{Mg})$ ratio.

Keywords: $\beta$-Tricalcium phosphate; Mg doping; XRD; Rietveld refinement.

(C) 2020 by the authors. This article is an open-access article distributed under the terms and conditions of the Creative Commons Attribution (CC BY) license (https://creativecommons.org/licenses/by/4.0/).

\section{Introduction}

The preparation of modified synthetic apatites mimetizing to natural bone has been of major interest for bone filling materials due to their similarity with the inorganic part of the major normal (bones and teeth) and pathological (dental caries, osteoporosis, atherosclerosis) calcified tissues of the human being [1,2]. Owing to their favorable biological response, these materials have been applied in a wide range of typologies like cement [3, 4]. Among these materials, there is the $\beta-\mathrm{Ca}_{3}\left(\mathrm{PO}_{4}\right)_{2}$ tricalcium phosphate $(\beta-\mathrm{TCP})$, which is used as a bone graft substitute in the form of granules or blocks, for non-load-bearing applications [5]. The $\beta$ polymorph of TCP, stable at room temperature, is preferred to the $\alpha$ - one (stable between $1180^{\circ} \mathrm{C}$ and $1400^{\circ} \mathrm{C}$ ), because of its biocompatibility, its higher mechanical strength and its lower dissolution rate [6]. $\beta$-TCP lattice is rhombohedral, space group R3c, $Z=21$ and cell parameters: $\mathrm{a}=\mathrm{b}=10.43 \AA, \mathrm{c}=37.39 \AA, \alpha=\beta=90^{\circ}, \gamma=120^{\circ}[7,8]$. However, this structure is often modified by the addition of dopants. Indeed, several studies focused on the ionic replacements, especially the replacement of $\mathrm{Ca}$ ions with divalent cations [9-12]. TCP structure can accommodate a large number of small-sized metal cations partially replacing calcium, such 
as $\mathrm{Mg}, \mathrm{Mn}, \mathrm{Fe}, \mathrm{Ni}, \mathrm{Co}, \mathrm{Cu}$ and $\mathrm{Zn}$ [10], [12-16], as well as divalent cations larger than $\mathrm{Ca}$ such as $\mathrm{Ba}$ and $\mathrm{Sr}[14,17]$. Mg-doped TCP exhibits the most valuable results in terms of stabilization [18,19]. Enderle [20] and Araujo et al. [21] also studied the maximum substitution of magnesium for calcium sites in Mg- $\beta$-TCP. The value of nearly $15.00 \mathrm{~mol} \%$ of $\mathrm{Ca}^{2+}$ can be replaced by $\mathrm{Mg}^{2+}$ in $\beta$ TCP, which was found.

$\beta$-TCP structure can be described as a regular assembly of two kinds of columns in which calcium atoms and phosphate tetrahedra are stacked. Calcium ions in $\beta$-TCP occupy five different cation sites: $\mathrm{Ca}(1), \mathrm{Ca}(2)$ and $\mathrm{Ca}(3)$ occupy general positions with eight to nine coordinated oxygens, whereas both $\mathrm{Ca}(4)$ and $\mathrm{Ca}(5)$ occupy special positions, with an effective multiplicity of $1 / 3$ of the other cation sites. $\mathrm{Ca}(4)$ site is only half occupied and exhibits a quite distorted nine coordination [8], $\mathrm{Ca}(5)$ exhibits approximately octahedral coordination. Phosphorus exhibits three crystallographically different positions: $\mathrm{P}(1), \mathrm{P}(2)$, and $\mathrm{P}(3)$. The multiplicity of $\mathrm{P}(1)$ equals to $1 / 3$ of those of $\mathrm{P}(2)$ and $\mathrm{P}(3)$, since it is in a special position. As shown in Figure 1 [17], the unit cell view down c-axis allows to identify A-type columns filled with $\mathrm{P}(1), \mathrm{Ca}(4)$ and $\mathrm{Ca}(5)$ and whereas $\mathrm{B}$-type columns contain $\mathrm{P}(2), \mathrm{P}(3), \mathrm{Ca}(1), \mathrm{Ca}(2)$, and $\mathrm{Ca}(3)$. A-type columns are surrounded only by B-type ones.

The purpose of the present research has been to study the effect of partial magnesium substitution for calcium on the crystal-chemical properties of TCP synthesized through wet chemical precipitation at $650^{\circ} \mathrm{C}$. Characterization methods such as X-ray diffraction analysis, Fourier transformed infrared spectroscopy and inductively coupled plasma optical emission spectroscopy were utilized to investigate the structural properties of obtained powder. The molecular formula and structural refinement were obtained using the Rietveld method (Fullprof-suite software).
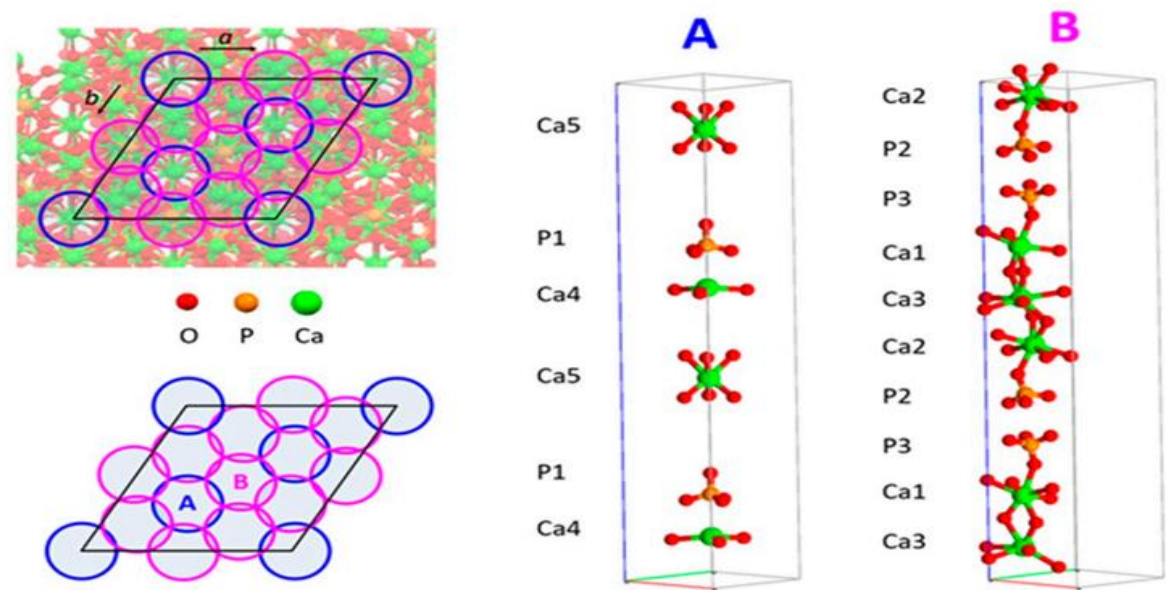

Figure 1. Left, views of the $\beta$-TCP unit cell down the c-axis. Right, a view of the atoms that characterize A-and B-type 'columns'[17].

\section{Materials and Methods}

\subsection{Experimental.}

Magnesium substituted calcium-deficient apatite (Mg-CDA) with $\mathrm{Mg} /(\mathrm{Ca}+\mathrm{Mg}$ ) ratio equal to 0.08 was synthesized by precipitation method according to the method described in our previous studies [22,23]. Mg-CDA was synthesized from an aqueous solution of calcium hydroxide 1.25M [Ca(OH) 2$]$ (Scharlau, Spain), orthophosphoric acid 2.85M [ $\left.\mathrm{H}_{3} \mathrm{PO}_{4}\right]$ (Riedelde Haën, $85 \%$ ) and magnesium chloride $\left[\mathrm{MgCl}_{2} .6 \mathrm{H}_{2} \mathrm{O}\right]$ (Riedel-de Haën, Germany) at $40^{\circ} \mathrm{C}$, $\mathrm{pH}=9 . \mathrm{MgCl}_{2} \cdot 6 \mathrm{H}_{2} \mathrm{O}$ was added slowly to the continuously stirred solution of $\mathrm{Ca}(\mathrm{OH})_{2}$. The 
aqueous solution of $\mathrm{H}_{3} \mathrm{PO}_{4}$ was added rapidly to the above solution containing calcium and Magnesium ions using a vigorous stirring. The nominal composition, $(\mathrm{Ca}+\mathrm{Mg}) / \mathrm{P}$ ratio, was maintained at 1.50. The precipitate was aged in mother liquors at room temperature for $24 \mathrm{~h}$, washed with distilled water, vacuum filtered, and finally dried $24 \mathrm{~h}$ in an oven at $80^{\circ} \mathrm{C}$. The as dried sample was further calcined $10 \mathrm{~h}$ at $650^{\circ} \mathrm{C}$.

\subsection{Characterization.}

Content of $\mathrm{Ca}, \mathrm{Mg}$, and $\mathrm{P}$ in the reaction product were quantified by the inductively coupled spectrometer (Shimadzu, ICP Spectrometer ICP-9000). The crystalline phase composition was determined by X-ray powder diffraction (XRD) using a XPERT-PRO diffractometer working with $\mathrm{Cu} \mathrm{K \alpha}$ radiation at $40 \mathrm{kV}$ and $30 \mathrm{~mA}$; the measurement was carried out in the $2 \theta$ range of 5-80 ${ }^{\circ}$, with a step of 0.017 and Scan Step Time 34(s). The acquired spectrum was analyzed by the Rietveld method-based software (Fullprof-suite) using \#13-0404 Mg-TCP phase PFD card as a structural model. The characteristic functional groups of Mg-TCP were identified by Fourier transform infrared (FTIR) spectroscopy, VERTEX 70, Genesis Series (400-4000 $\mathrm{cm}^{-1}$, resolution 4 , scans 20 ). For this, $1 \%$ of the powder was mixed and ground with $99 \% \mathrm{KBr}$, and the spectrum was taken in the range of 400 to $4000 \mathrm{~cm}^{-1}$.

\section{Results and Discussion}

Based on ICP results, the $(\mathrm{Ca}+\mathrm{Mg}) / \mathrm{P}$ and $\mathrm{Mg} /(\mathrm{Ca}+\mathrm{Mg})$ molar ratios of $\beta$-TCP were calculated to be 1.52 and 0.088 , respectively, which is close to the theoretical values $[(\mathrm{Ca}+\mathrm{Mg}) / \mathrm{P}=1.5$ and $0.08 \mathrm{~mol}$ of $\mathrm{Mg}]$. Also, the $\mathrm{Ca} / \mathrm{P}$ ratio of $\beta-\mathrm{TCP}$ was 1.38 .

The Fourier Transform Infrared Spectroscopy of the powder calcined at $650^{\circ} \mathrm{C}$ for 10 hours (Fig. 2) shows several absorption bands, including those with 552, 594, 945.972, 1025 and $1120 \mathrm{~cm}^{-1}$ that are attributed to the vibration of $\mathrm{PO}_{4}{ }^{3-}$ groups in the $\beta$-TCP structure. This analysis also shows the absence of characteristic bands of pyrophosphate $\left(\mathrm{P}_{2} \mathrm{O}_{7}{ }^{2-}\right)$ groups (1200-1100 $\left.\mathrm{cm}^{-1}\right)$ and $\mathrm{OH}^{-}$ions attributed to the hydroxyapatite phase $\left(3560 \mathrm{~cm}^{-1}\right.$ and $630 \mathrm{~cm}^{-}$ ${ }^{1}$ ). The calcination of the $\mathrm{Mg}$-CDA to $650^{\circ} \mathrm{C}$ leads to the formation of a pure $\mathrm{Mg}-\beta$-TCP phase.

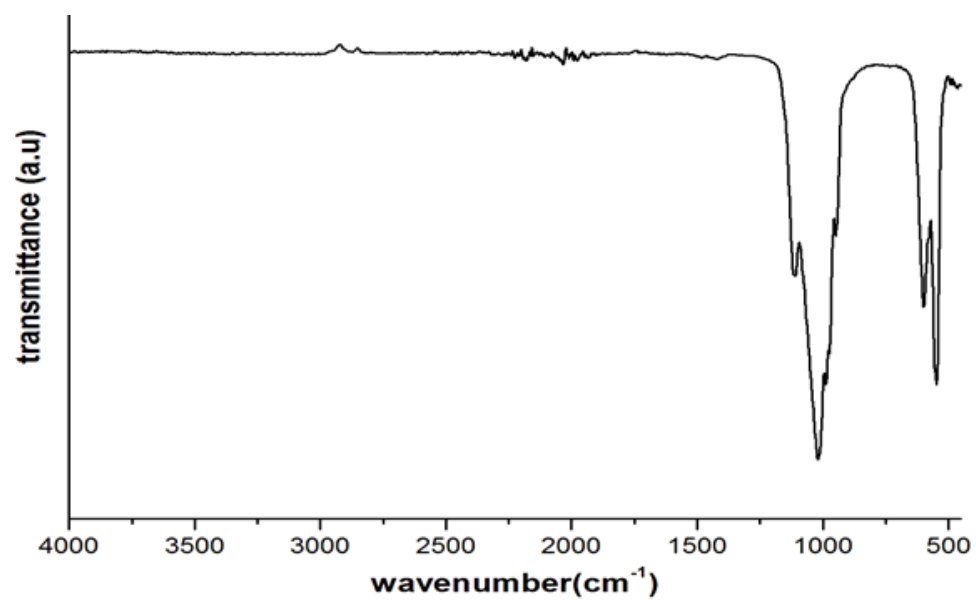

Figure 2. FTIR spectrum of calcined $\mathrm{Mg}$-Ca-deficient apatite at $650^{\circ} \mathrm{C}$.

The XRD profile showed that the sintered Mg-CDA sample was completely transformed to the magnesian ( $\beta$-Mg-TCP-JCPDS 13-0404 card) phase; also, not a significant amount of secondary phase has been identified. The structural refinement was performed by the Rietveld method [24] using FULLPROF software [25], starting from the atomic position 
set of $\beta$-Mg-TCP in space group R3c [26]. The Rietveld analyses modeled the backgrounds by a linear interpolation function and the shape of the peaks by a pseudo-voight function. The sum of the occupancy factors (OF) of calcium and of the magnesium ion in each metal (M) site was imposed on unity, with the exception of site M(4), which was 0.43 in accordance with $\beta$-TCP structure [8]. In the sites shared by $\mathrm{Ca}$ and $\mathrm{Mg}$, no constraint was imposed on the overall metal atoms content, and no attempt was made to differentiate the calcium positions from the magnesium ones (the position and the thermal parameter of both occupants were constrained to be equal).

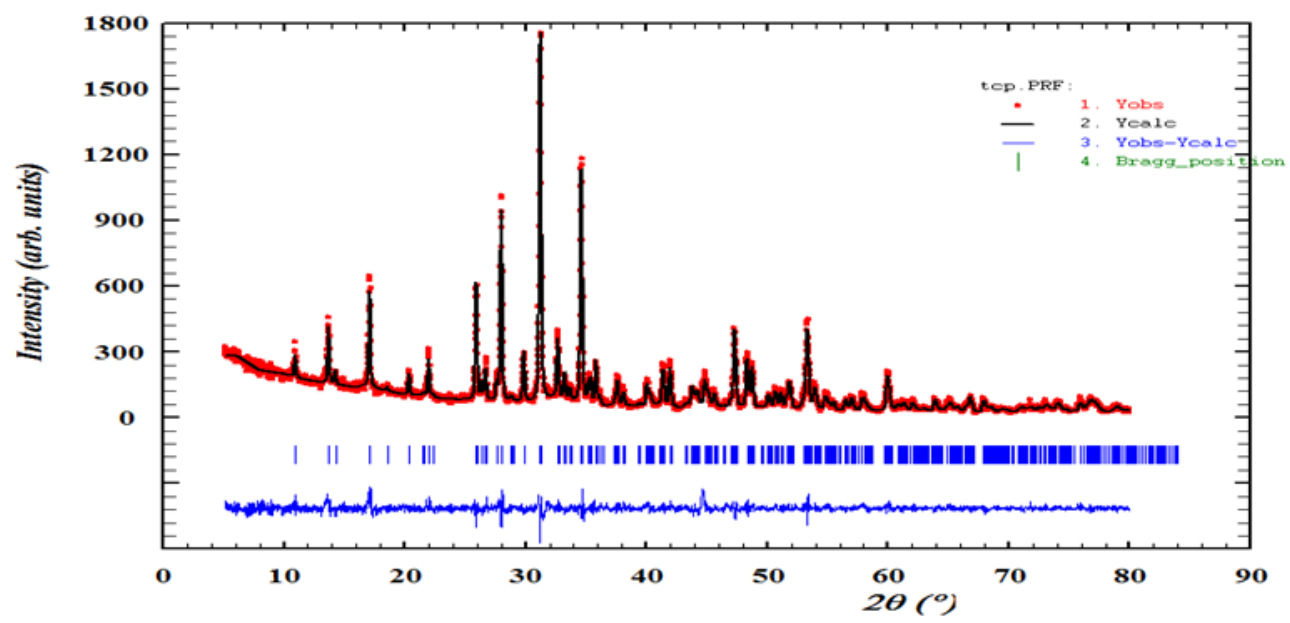

Figure 3. Comparison of the observed (red) and calculated (black) patterns of Mg-TCP. At the bottom, reflection markers and curve difference.

Table 1. Lattice parameters and agreement factors for calcined Mg-TCP.

\begin{tabular}{l|l} 
Unit cell parameters & $\mathrm{a}=\mathrm{b}=10,3560(3) \AA ; \mathrm{c}=37,1718(6) \AA$ \\
& $\alpha=\beta=90^{\circ} ; \gamma=120^{\circ}$ \\
\hline Hermann-Manguin symbol & $\mathrm{R} 3 \mathrm{c}$ \\
Volume $\left(\AA^{3}\right)$ & $\mathrm{V}=3452.44$ \\
Bragg R-factor & $\mathrm{R}_{\mathrm{Bragg}}=5.53$ \\
$\mathrm{Rf}-$ factor & $\mathrm{R}_{\mathrm{F}}=3.82$ \\
$\mathrm{R}$ factors & $\mathrm{R}_{\mathrm{P}}=19, \mathrm{R}_{\mathrm{WP}}=20$ \\
Chi-squared $\chi^{2}$ & $\chi^{2}=1.32$
\end{tabular}

The principal crystal structure refinements data are reported in Table 1, while in Figure 3 , the agreement between the observed (red line) and the calculated (black line) diffraction pattern is displayed, together with the difference pattern plotted on the same scale (blue curve). $\beta$-TCP structure has the $\mathrm{Ca}(4)$ and $\mathrm{Ca}(5)$ sites for ion substitution. The $\mathrm{Ca}(4)$ and $\mathrm{Ca}(5)$ sites have 9-coordination and 6-coordination, respectively, with oxygen. These atomic sites well accommodate divalent cations with ionic radii from 0.060 to $0.080 \mathrm{~nm}$ corresponding typically to $\mathrm{Mg}(0.072 \mathrm{~nm})$ [26]. Table 1 shows the lower values found for all $\mathrm{R}$-Factor $\left(\mathrm{R}_{\mathrm{wp}}, \mathrm{R}_{\mathrm{Bragg}}, \mathrm{R}_{\mathrm{P}}\right.$, and $R_{F}$ ) denoting that the refined structural model was adequate to describe the crystal of the calcined sample. The $\mathrm{a}=\mathrm{b}$ and $\mathrm{c}$ lattice parameters calculated values of 10.3560(3) and 37.1718(6) A, respectively (table 1), are lower than the $\beta$-TCP cell parameters without magnesium and they are in good agreement with those of the reference sample [20]. This contraction in lattice parameters is due to the substitution of $\mathrm{Ca}^{2+}$ ion $\left(1.00 \AA\right.$ ) by $\mathrm{Mg}^{2+}$ ion, with a lower ionic radius of $(0.72 \AA)$. According to Clement et al. [27], the Mg-for-Ca substitution causes a contraction in the a and c-axis parameters when the $\mathrm{Mg} /(\mathrm{Ca}+\mathrm{Mg})$ ratio is less than $9.5 \%$. Further substitution causes a contraction in the a-axis parameter and an elongation in the c-axis parameter. This unusual change in lattice parameters is attributed to preferred $\mathrm{Mg}$ replacement for the Ca sites in order of $\mathrm{Ca}(5)$ followed by $\mathrm{Ca}(4)$, since the full 
occupation of $\mathrm{Mg}$ in the $\mathrm{Ca}(5)$ sites corresponds to a $\mathrm{Mg} /(\mathrm{Ca}+\mathrm{Mg})$ ratio of $9.5 \%$ [27]. The occupancy values obtained from the Rietveld refinement were used to estimate the inclusion of the $\mathrm{Mg}^{2+}$ in the $\beta$-TCP lattice quantitatively. Table 2 shows the atomic occupation site of each calcium atom as well as the respective calculated occupancy factor. The $\mathrm{Mg} 4$ and $\mathrm{Mg} 5$ calculated occupancy factors equal to $0.716(6)$ and $0.256(2)$, respectively. The total number of atoms is equal to the sum of the number of atoms multiplied by the occupancy factor, resulting in 5.86 and 57.15 atoms for $\mathrm{Mg}$ and $\mathrm{Ca}$ sites, respectively. The formula $\mathrm{Ca}_{2.72}$ $\left(\mathrm{Mg} 4_{0.07} \mathrm{Mg} 5_{0.21}\right)\left(\mathrm{PO}_{4}\right)_{2}$ was then obtained; this corresponds to a $9.3 \% \mathrm{Mg} /(\mathrm{Ca}+\mathrm{Mg})$. The results of the structural refinements show that magnesium is distributed over the two sites in $\mathrm{Mg}$-TCP and that the site M(4) started to fill before the site M(5) is completely filled. This could be considered rather unusual compared with references [20, 26, 28].

Table 2. Refined fractional atomic coordinates, Multiplicity of site, isotropic displacement atomic parameters,

\begin{tabular}{l|l|l|l|l|l|l}
\multicolumn{7}{c}{ and occupancy factors for $\mathrm{Ca}_{2.72} \mathrm{Mg}_{0.28}\left(\mathrm{PO}_{4}\right)_{2}}$. \\
Atom & Mult & $\mathbf{x}$ & $\mathbf{y}$ & $\mathbf{z}$ & $\mathbf{B}$ & Occ \\
\hline Ca1 & 18 & 0.72139 & 0.85793 & 0.16710 & 0.791 & 1.000 \\
Ca2 & 18 & 0.61785 & 0.81967 & -0.03379 & 0.300 & 1.000 \\
Ca3 & 18 & 0.72698 & 0.85125 & 0.06194 & 0.800 & 1.000 \\
Ca4 & 6 & 0.00000 & 0.00000 & -0.08238 & 2.573 & 0.174 \\
Mg4 & & & & & & 0.256 \\
Ca5 & 6 & 0.00000 & 0.00000 & 0.72780 & 2.322 & 0.284 \\
Mg5 & & & & & & 0.716 \\
P1 & 6 & 0.00000 & 0.00000 & 0.00000 & 1.160 & 0.333 \\
P2 & 18 & 0.69262 & 0.86933 & 0.86951 & 0.300 & 1.000 \\
P3 & 18 & 0.65789 & 0.85094 & 0.76716 & 0.140 & 1.000 \\
O1 & 18 & 0.74962 & -0.08336 & -0.09399 & 0.598 & 1.000 \\
O2 & 18 & 0.75403 & 0.76683 & 0.85777 & 1.866 & 1.000 \\
O3 & 18 & 0.72974 & 0.01206 & 0.84415 & 0.964 & 1.000 \\
O4 & 18 & 0.53162 & 0.76624 & 0.86558 & 0.124 & 1.000 \\
O5 & 18 & 0.59951 & -0.05333 & 0.77813 & 1.277 & 1.000 \\
O6 & 18 & 0.56991 & 0.68790 & 0.78512 & 1.481 & 1.000 \\
O7 & 18 & 0.08315 & 0.91227 & 0.77885 & 0.155 & 1.000 \\
O8 & 18 & 0.62798 & 0.82741 & 0.72610 & 0.382 & 1.000 \\
O9 & 18 & 0.00757 & 0.86054 & -0.01320 & 1.069 & 1.000 \\
O10 & 6 & 0.00000 & 0.00000 & 0.03397 & 1.041 & 0.333
\end{tabular}

\section{Conclusions}

In this work, we synthesized the $\beta$-TCP compound doped with $\mathrm{Mg}$ by precipitation method. XRD and FTIR analyses showed that the MgCDA sample calcined at $650{ }^{\circ} \mathrm{C}$ was transformed, as a single phase, into $\mathrm{Mg}$-substituted tricalcium phosphate, $\mathrm{Mg}-\beta$-TCP provoking a reduction of the cell parameters. The crystallographic study has brought new important information on the structural location of $\mathrm{Mg}$ cation in the $\beta$-TCP phase. Rietveld refinement shows that $\mathrm{Mg}^{2+}$ is incorporated in the $\beta$-TCP structure by substituting calcium atoms in both $\mathrm{Ca}(4)$ and $\mathrm{ca}(5)$ crystallographic sites, but the M4 site started filling up before the M5 site was completely filled. The approximately stoichiometric formula $\mathrm{Ca} 2.72$ $\left(\mathrm{Mg}^{\mathrm{IV}}{ }_{0.07} \mathrm{Mg}^{\mathrm{V}}{ }_{0.21}\right)\left(\mathrm{PO}_{4}\right)_{2}$ was proposed for the $\mathrm{Mg}-\beta$ - TCP crystal from the refined occupancy factors corresponding to a $9.3 \% \mathrm{Mg} /(\mathrm{Ca}+\mathrm{Mg})$.

\section{Funding}

This research received no external funding.

\section{Acknowledgments}

This research has no acknowledgment. 


\section{Conflicts of Interest}

\section{The authors declare no conflict of interest.}

\section{References}

1. Dorozhkin, S.V. Multiphasic calcium orthophosphate $\left(\mathrm{CaPO}_{4}\right)$ bioceramics and their biomedical applications. Ceram. Int. 2016, 42, 6529-6554, https://doi.org/10.1016/j.ceramint.2016.01.062.

2. Bigi, A.; Boanini, E. Functionalized biomimetic calcium phosphates for bone tissue repair. J. Appl. Biomater. Funct. Mater. 2017, 15, 313-325, https://doi.org/10.5301/jabfm.5000367.

3. Fathi, M.; Kholtei, A.; EL Youbi, S.; Chafik El Idrissi, B. Setting Preperties of Calcium Phosphate Bone Cement. Materials Today: Proceedings 2019, 13, 876-881, https://doi.org/10.1016/j.matpr.2019.04.051.

4. Fathi, M.; Massit, A.; El Yacoubi, A.; Chafik El Idrissi, B. Development of an apatitic calcium phosphate cements: effect of liquid/poder ratio on the setting time. Mor. J. Chem 2020, 8, 176-183.

5. Gremillard, L.; Meille, S.; Chevalier, J.; Zhao, J. Fridrici,; V. Kapsa, P.; Geringer, J.; Uribe, J. Degradation of Bioceramics. In: Degradation of Implant Materials. Springer, New York; USA, Volume 9, 2012; https://doi.org/10.1007/978-1-4614-3942-4_9.

6. Ryu Hyuk-Joon, H.S.Y.; Kug Sun, H.; Bong-Sun, C.; Choon-Ki, L.; SungSoo, C. An improvement in sintering property of b-tricalcium phosphate by addition of calcium pyrophosphate. Biomaterials 2002, 23, 909-914, https://doi.org/10.1016/s0142-9612(01)00201-0.

7. Li, X.; Ito, A.; Sogo, Y.; Wang, X.; LeGeros, R.Z. Solubility of Mg-containing $\beta$-tricalcium phosphate at $25^{\circ}$ C. Acta Biomater. 2009, 5, 508-517, https://doi.org/10.1016/j.actbio.2008.06.010.

8. Yashima, M.; Sakai, A.; Kamiyama, T.; Hoshikawa, A. Crystal structure analysis of $\beta$-tricalcium phosphate Ca3(PO4)2 by neutron powder diffraction. J. Solid State Chem 2003, 175, 272-277, https://doi.org/10.1016/S0022-4596(03)00279-2.

9. Gallo, M.; Le Gars Santoni, B.; Douillard, T.; Zhang, F.; Gremillard, L.; Dolder, S.; Hofstetter, W.; Meille, S.; Bohner, M.; Chevalier, J.; Tadier, S.; Hofstetter, W.;Meille, S.; Bohner, M.; Chevalier, J.; Tadier, S. Effect of grain orientation and magnesium doping on $\beta$-tricalcium phosphate resorption behavior. Acta Biomaterialia 2019, 89, 391-402, https://doi.org/10.1016/j.actbio.2019.02.045.

10. Tkachenko, S.; Horynová, M.; Casas-Luna, M.; Diaz-de-la-Torre, S.; Dvořák, K.; Celko, L.; Kaiser, J.; Montufar, E.B.Strength and fracture mechanism of iron reinforced tricalcium phosphate cement fabricated by spark plasma sintering J. Mech. Behav. Biomed. Mater. 2018, 81, 16-25, https://doi.org/10.1016/j.jmbbm.2018.02.016.

11. Kannan, S.; Lemos, I.A.F.; Rocha, J.H.G.; Ferreira, J.M.F. Synthesis and characterization of magnesium substituted biphasic mixtures of controlled hydroxyapatite/ $\beta$-tricalcium phosphate ratios. J. Solid State Chem 2005, 178, 3190-3196, https://doi.org/10.1016/j.jssc.2005.08.003.

12. Frasnelli, M.; Pedranz, A.; Biesuz, M.; Dirè, S.; Sglavo, V.M. Flash sintering of Mg-doped tricalcium phosphate (TCP) nanopowders. Journal of the European Ceramic Society 2019, 39, 3883-3892, https://doi.org/10.1016/j.jeurceramsoc.2019.05.007.

13. Sinusaite, L.; Renner, A.M.; Schütz, M.B.; Antuzevics, A.; Rogulis, U.; Grigoraviciute-Puroniene, I.; Mathur, S.; Zarkov, A. Effect of Mn doping on the low-temperature synthesis of tricalcium phosphate (TCP) polymorphs. Journal of the European Ceramic Society 2019, 39, 3257-3263, https://doi.org/10.1016/j.jeurceramsoc.2019.03.057.

14. Matsunaga, K.; Kubota, T.; Toyoura, K.; Nakamura, A. First-principles calculations of divalent substitution of $\mathrm{Ca}(2+)$ in tricalcium phosphates. Acta Biomater. $2015 \quad 23, \quad 329-337$, https://doi.org/10.1016/j.actbio.2015.05.014.

15. Belik, A.A.; Morozov, V.A.; Khasanov, S.S.; Lazoryak, B.I. Crystal structures of new double calcium and cobalt phosphates. Mater. Res. Bull.1998, 33, 987-995, https://doi.org/10.1134/1.1312910.

16. Altomare, M.; Rizzi, R.; Rossi, M.; El Khouri, A.; Elaatmani, M.; Paterlini, V.; Ventura, G.D.; Capitelli, F. New Ca2.90(Me2+)0.10(PO4)2 $\beta$-tricalcium Phosphates with Me2+ = Mn, Ni, Cu: Synthesis, CrystalChemistry, and Luminescence Properties. Crystals 2019, 9, https://doi.org/10.3390/cryst9060288.

17. Boanini, E.; Gazzano, M.; Nervi, C.; Chierotti, M.R.; Rubini, K.; Gobetto, R.; Bigi, A. Strontium and Zinc Substitution in $\beta$-Tricalcium Phosphate: An X-ray Diffraction, Solid State NMR and ATR-FTIR Study. J. Funct. Biomater 2019, 10, https://doi.org/10.3390/jfb10020020.

18. Matsumoto,N.; Yoshida, K.; Hashimoto, K.; Toda, Y. Thermal stability of b-tricalcium phosphate doped with monovalent metal ions, Mater. Res. Bull. 2009, 44, 1889-1894, https://doi.org/10.1016/j.materresbull.2009.05.012.

19. Cheng, G.; Deng, C.; Wu, C.; Yin, H.; Ruan, Y.; Sun, Y.; Xie, Q.; Wu, X. Effects of Mn-doping on the structural evolution of b-Tricalcium Phosphate by Rietveld refinement and Raman spectroscopy. Materials Letters 2019, 235, 236-238, https://doi.org/10.1016/j.matlet.2018.10.031.

20. Enderle, R.; Gotz-Neunhoeffer, F.; Gobbels, M.; Muller, F.A.; Greil, P. Influence of magnesium doping on the phase transformation temperature of $\beta$-TCP ceramics examined by Rietveld refinement. Biomaterials 2005, 26, 3379-3384, https://doi.org/10.1016/j.biomaterials.2004.09.017. 
21. Araújo, J.C.; Sader, S; Moreira, EL; Moraes, C.A.; LeGeros, Z.; Soares, G.A. Maximum substitution of magnesium for calcium sites in Mg--TCP structure determined by X-ray powder diffraction with the Rietveld refinement. Materials Chemistry and Physics 2009 118, 337-340, http://dx.doi.org/10.1016/j.matchemphys.2009.07.064.

22. Massit, A.; El Yacoubi, A.; Rezzouk, A.; Chafik El Idrissi, B. Thermal Behavior of Mg-Doped CalciumDeficient Apatite and Stabilization of $\beta$ Tricalcium Phosphate. Biointerface Research in Applied Chemistry 2020, 10, 6837-6845, https://doi.org/10.33263/BRIAC106.68376845.

23. Massit, A.; El Yacoubi, A.; Kholtei, A.; Chafik El Idrissi, B. XRD and FTIR Analysis of Magnesium Substituted Tricalcium Calcium Phosphate Using a Wet Precipitation Method. Biointerface Research in Applied Chemistry 2021, 11, 8034-8042, https://doi.org/10.33263/BRIAC111.80348042.

24. Young, R.A. The Rietveld Method. Oxford University Press: Oxford, UK, 1995.

25. Rodriguez-Carvajal, J. Recent advances in magnetic structure determination by neutron powder diffraction. Physica B 1993, 192, 55-69, https://doi.org/10.1016/0921-4526(93)90108-I.

26. Schroeder, L.W.; Dickens, B.; Brown, W.E. Crystallographic studies of the role of Mg as a stabilizing impurity in - $\mathrm{Ca}_{3}\left(\mathrm{PO}_{4}\right)_{2} \mathrm{I}$. Refinement of Mg-containing - $\mathrm{Ca}_{3}\left(\mathrm{PO}_{4}\right)_{2}$. Journal of Solid State Chemistry. 1977, 22, 253-262.

27. Clement, D.; Tristan, J.M.; Hamad, M.; Roux, P.; Heughebaert, J.C. Etude de la substitution $\mathrm{Mg}^{2+/} \mathrm{Ca}^{2+}$ dans l'orthophosphate tricalcique $\beta$. J Solid State Chem.1989, 78, 271-280, https://doi.org/10.1016/00224596(89)90108-4.

28. Sader, E.L. Moreira, M.S.; Moraes, V.C.A.; Araújo, J.C.; LeGeros, R.Z.; Soares, G.A. Rietveld Refinement of Sintered Magnesium Substituted Calcium Apatite. Key Engineering Materials 2009, 396-398, 277-280, https://doi.org/10.4028/www.scientific.net/KEM.396-398.277. 